\title{
Interactional Organization and Pedagogic Aims of Reading Aloud Practices in L1 Education
}

\author{
Liisa Tainio ${ }^{\star}$ and Anna Slotte \\ University of Helsinki, Finland
}

\begin{abstract}
The aim of this article is to examine the students' and teachers' activities of reading aloud as it occurs in and through interaction in L1-classrooms in the sixth grade with 12-year-old students. Our data consists of video-recorded classroom interaction in Finnish comprehensive schools. The method adopted is conversation analysis. This analysis encompasses read-alouds with reference to genre, source of the text and recipients' visual access or non-access to the text. According to our analysis, the reading aloud a text is used to create a shared reference point in classrooms in terms of allocating turns, emphasizing the importance of the content or ideology of the text, deepening the knowledge and motivation for learning, fostering writing skills, or merely to enjoy the text or to fill up lesson time. In the discussion we reflect on read-alouds as a pedagogical tool for developing literacy skills in a classroom setting.
\end{abstract}

Keywords: Read-aloud practices; literacy; classroom interaction; conversation analysis Received: May 2016; Accepted: January 2017; Published: March 2017

\section{Introduction}

In early childhood education and primary education, it is often recommended that teachers should read-aloud to pupils (see e.g. Johnston, 2016). However, teachers in the upper grades often read-aloud for their students (Albright \& Ariail, 2005). It has been shown that reading aloud is beneficial to language growth and awareness, it increases reading motivation and gives positive experiences, expands vocabulary and offers models of various linguistic and textual structures, gives information, and helps particularly struggling readers to grasp the meaning of the text as well as to critically reflect on the text (e.g., Albright \& Ariail, 2005; Clark \& Andreasen, 2014; Roe 2014, 163-165). In addition to all of these benefits, according to student surveys, pupils enjoy the moments of teachers reading aloud (Clark \& Andreasen, 2014). Particularly

^Correspondence to: Liisa Tainio, University of Helsinki, Finland. Email: liisa.tainio@helsinki.fi 


\section{Tainio and A. Slotte}

L1 teachers read aloud often, especially fictional texts but also other kinds of texts (Albright \& Ariail, 2005).

In addition, pupils and students are often instructed to read-aloud during lessons. Approximately one-third of the countries involved in the PIRLS1 1 assessment, state in their L1 reading curricula that "reading aloud with fluency and correct intonation" is an important goal (PIRLS, 2012, pp. 12-13). According to research literature, student read-alouds are often used as a diagnostic tool to measure the quality of reading literacy skills (Reschly, Busch, Betts, Deno \& Long, 2009) but in classrooms, it is also used for other purposes (Goodman \& Goodman, 2013; Roe, 2014).

Although the Finnish curriculum does not include reading aloud in its objectives in primary or secondary education, this activity is often present during the lessons in Finnish schools from lower to upper grades. According to our observations on our video recorded classroom data, consisting of sixth grade classroom interaction, both students and teachers read-aloud often during L1 lessons. Even if it has been demonstrated that teacher read-alouds decrease when students get older (Ariail \& Albright, 2006), we observed this activity on nearly all of the sixth grade lessons in our data. This state of affair raised our curiosity: What is going on in Finnish L1-lessons when the teacher or student is reading aloud for other participants? What are the interactional and pedagogical motivations of this activity?

This article focuses on the student and teacher practices of reading aloud during classroom interaction in L1 education (referred to as "mother tongue and literature" in the Finnish national curriculum; see Tainio \& Grünthal, 2012). By reading aloud we mean all the practices where teacher or student reads aloud from a written text, including textbooks, fictional texts, non-fictional texts, student texts, instructions, texts on the whiteboard, and other curriculum materials. Working with texts composes the majority of classroom tasks in L1 lessons, and during these tasks, the students and the teacher often read-aloud different types of texts.

Even if the activities of teacher read-alouds have been a focus of several studies (see e.g. Clark \& Andreasen, 2014), the studies on reading aloud practices in upper grades remain as exceptions. For example, Albright and Ariail (2005) and Ariail and Albright (2006) have conducted surveys on US middle school teachers on their read-aloud practices, and they found out that teachers often use this pedagogic tool in their teaching. Particularly language art teachers read fictional texts but also non-fictional texts, which were preferred by teachers of other subjects. The reasons for read-alouds varied among teachers, the main reasons being the modeling of reading practices, making texts available for all students, increasing the understanding of the text, and reinforcing content knowledge (Albreight \& Ariail, 2005, p. 584). Clark and Andreasen (2014) conducted a survey among sixth grade students to find out what they thought about teacher read-alouds and how they experienced them. All students enjoyed these moments, but for different reasons. Those who did not like reading themselves enjoyed the relaxed situation in the classroom and the possibility not to be actively responsible for reading; those who liked reading themselves enjoyed the texts that were read-aloud, especially if the teacher initiated text related discussions after reading. In spite of these few studies introduced above, 
scholars of this field find empirical research on read-aloud activities of middle school aged students very limited, and call for more studies in this age group (Clark \& Andreason, 2014, p. 163; Ariail \& Albright, 2006, p. 71).

In this article we would like to answer this call by using conversation analysis to analyze empirically video-recorded, naturally occurring sixth grade L1 classroom interaction from Finnish comprehensive schools. We find our analysis adding to the existing body of research in three ways. First, we will study both teacher and student read-alouds which gives a new perspective to the activity. It has not been common in the earlier research to study both teacher and student read-alouds using the same framework. By studying the practices of all participants in a same study, using the same analytic tools, we want to highlight the importance of public talk as a mutual achievement in the classroom setting: teachers and students create not only the interactional space but also the pedagogical content together. Second, in studying also student read-alouds we hope to open a new perspective on this pedagogical method, typically reported and studied merely as a diagnostic tool. We would like to suggest that student read-alouds have also many other functions, and that they can be used in various ways for the benefit of developing literacy skills. Third, since studies on the functions and meanings of read-alouds in sixth grade have mostly been conducted by using surveys or interviews, we offer here a new perspective on this phenomenon. By including detailed analysis of interaction into the description of read-aloud activities we are able to show, in turn-by-turn basis, how this activity is introduced, conducted and finished in the course of classroom interaction. We hope thus to give a more precise perspective on the sequential and embodied management of read-alouds in classroom interaction.

The conversation analytic perspective with its inductive analysis is related to the sociocultural perspective on literacy education and reading as a situated activity which is adopted in this study (Bagga-Gupta, Evaldsson, Liberg \& Säljö, 2013; Baker, 1991; Gee, 2013; Heap, 1991). We will examine the management of read-aloud practices in reference to four main points. First, we will examine what are the text sources and genres that are read-aloud in the classroom settings. Second, we will take seriously the interactionally important aspects of these situations, namely whether the recipients' (students and/or teacher) have a visual access to the text or not. Third, we will analyze representative examples of different read-aloud practices to examine how they are sequentially managed in the classroom interaction and, finally, what kind of pedagogic practices can be identified to be intertwined in the details of verbal and embodied interaction. In short, in this article we intend to answer the following research questions:

1. What are the main sources and genres of texts that are read-aloud in sixth grade L1 classrooms in Finnish schools?

2. How is reading aloud sequentially managed in and through the verbal and embodied practices of classroom interaction?

3. How do the recipients' access or non-access to the text influence the read-aloud activity? 


\section{Tainio and A. Slotte}

4. What are the pedagogic consequences of different read-aloud activities that can be interpreted from the observation and analysis of the data?

The results of the first research question will be presented in Table 1 that visualizes the distribution of the sources and genres read-aloud in the analyzed material. Through the sequential analysis of read-aloud activities in our data we found that the participants' (teachers and students) visual access to the text had consequences for the interactional practices around the reading activities. These findings lead to a decision to divide the presentation of the analysis in two parts according to the members' access to the text. Reflections of pedagogic consequences for developing literacy skills are summarized in the final discussion, and we ground them on the results that we have achieved in answering research questions from one to three.

\section{Reading aloud as an interactional phenomenon}

In a sociocultural approach, literacy skills are considered to be developed through socially and culturally situated activities, in literacy events and through literacy practices (Baker, 1991; Bagga-Gupta et al., 2013). For this reason, sharing a text with others has been viewed as a practice to increase motivation for reading and writing (Guthrie \& Wigfield, 2000; Murray, 2009). The act of reading aloud is particularly effective, as it allows the reader to share the literacy event with others during the actual reading activity (Roe, 2014; Tainio \& Siponmaa, 2015b). While reading aloud, the reader can also share the emotions and feelings that the text evokes, and the participants in this reading event can express shared understandings about its values and cultural meanings (Baker, 1991; Gee, 2013; Davidson, Danby, Given \& Thorpe, 2014).

In studies on interaction conducted using conversation analysis, the functions of reading aloud activities have been described in connection to the interactional purpose and sequential details of the ongoing verbal and embodied interaction. The importance of texts as both material and cognitive artefacts has been emphasized in the recent conversation analytic research (Nevile, Haddington, Heinemann \& Rauniomaa, 2014). Especially in institutional contexts, reading aloud a text can be used for organizing the interaction order and emphasizing the importance of the written information for the management and purpose of the ongoing situation (Femø Nielsen, 2012; Goodwin, 2007). For instance, reading aloud has been shown to offer a resource in interview situations or meetings, where read-alouds direct the topic and get recipients' attention to the same reference point (see, for example, Femø Nielsen, 2012; Mondada, 2011). In addition, in performance appraisal interview setting, the participants can, through read-alouds negotiate who is to take the next turn, what should be the topic of that turn, and whether the topic should be connected to the appraisal form (Mikkola \& Lehtinen, 2014). Read-alouds may also be used for the management of problematic situations, such as getting the interviewer to manage interview situations while asking problematic questions (Houtkoop Steenstra, 2000).

In conversation analytic studies on educational settings, where texts usually have an important role, reading aloud has been regarded as being intimately connected to 
organization and management of task activities (see, for example, Davidson et al., 2014; Ford, 1999; Jakonen, 2015; Pitkänen-Huhta, 2003). In her analysis on conducting laboratory tasks, Ford (1999) observed that in the process of working on a task, a silent and private reading preceded the practice of reading aloud in public. This in itself created a new text-based reference point for participants. Ford refers to this process as an example of "literacy in action" (Ford, 1999, p. 378). In her analysis of literacy practices in the EFL classrooms in Finnish schools, Pitkänen-Huhta (2003) analyzes the use of reading a textbook aloud while reviewing homework. The IRE turn-taking system (for instance, see Mehan, 1979) is closely related to the textbook design, particularly during the activity of teaching and learning the grammar of a foreign language (Pitkänen-Huhta, 2003). In group work settings, texts appear to be an important source for child-initiated learning (Melander \& Sahlström, 2010), student requests and information-seeking questions (Jakonen, 2015), and teacher explanations (Karvonen, Tainio, Routarinne \& Slotte, 2015; Tanner, 2014). The interactional analysis of the practice of using texts for the purposes of learning may also reveal the negotiation of students' epistemic and moral statuses in the creation of their institutional identities (Jakonen, 2015; Musk \& Cekaite, 2015). The management of problematic situations and discipline problems in classrooms may also be linked to the practice of working with texts (Damber, 2015). For example, some teachers exploit the activity of reading aloud to manage student behavior: a restless student can be asked to read-aloud "since you are already speaking" (Tainio, 2012).

In sum, only few studies have explored naturally occurring classroom interaction to identify and describe the interactional management of the different student and teacher read-aloud practices during L1 lessons. Even more seldom have the studies focused also on embodied aspects of interaction which, however, appear to be highly important for the management of read-aloud practices. Furthermore, there is a lack of empirical studies on read-alouds focused on such a high grade as year 6 . In what follows, we will first introduce our data and method, and then, after analyzing examples of different kinds of read-alouds, we reflect on the pedagogical consequences of read-alouds grounded on our data observations and analyses.

\section{Data and method}

The method of conversation analysis is used to analyze the data (see, for example, Sidnell \& Stivers, 2013). Conversation analysis is a qualitative approach that examines interaction from an ethnomethodological perspective, and its usefulness in analyzing literacy events has been widely recognized (Baker, 1997; Davidson, 2012; Heap, 1991). Conversation analysis aims to reveal the orderly practices of verbal and non-verbal interaction, concentrating on the micro-analysis of the participants' views, identified in observable activities (Sidnell \& Stivers, 2013). These observable indicators and practices form the basis of an intersubjective understanding that is treated, shared, and understood as such by participants. The benefits of conversation analysis for analyzing naturally occurring interaction in educational settings have 


\section{Tainio and A. Slotte}

ensured its place among the methods used in the learning sciences (Melander \& Sahlström, 2010; Rusk, Pörn, Sahlström \& Slotte-Lüttge, 2015; Tainio \& Laine, 2015a).

Our data corpus consists of 28 lessons that were video-recorded in 2004 and 2012, in both Finnish-speaking and Swedish-speaking comprehensive schools in Southern and Western Finland. The students in these sixth grade classes are approximately 12 years old, and with few exceptions, they read-aloud fluently. The data was collected for a research project, TextMix, that focuses on studying the use of texts in L1 education in the sixth grade that prepares students for the lower secondary school (see TextMix, 2014). For this reason, studying the literacy practices in the sixth grade is particularly important; the required literacy skills are more complex in the secondary school level. The conversation analytic transcription system was used to transcribe the data (see Appendix).

In this article, we will focus on the episodes that contain read-alouds of all kinds of texts and genres, and in situations where are all participants in the classroom are recipients. First, we identified and collected all the episodes that consisted this kind of reading aloud. In all but one lesson, at least one participant was engaged in the act of reading aloud. After identifying the episodes, we analyzed them in reference to the recipients' visual access to the text as well as the genre and the text source. Then we selected representative examples of different types of read-alouds. It was typical for the students to follow the teacher's instructions, and thus one of the criteria for selection was the students' agreement to follow the teacher's suggestions. In other words, for a detailed analysis, we identified representative episodes that were also pedagogically successful in terms of observable student involvement and participation. After doing these initial analyses of videos and transcripts, we ended up by selecting four examples to be analyzed in detail. However, in our analysis section, we will also occasionally refer to other observed read-alouds when we consider it necessary in respect to the richness of the data.

In our data, during the read-aloud event, the reader was either the teacher, or a student who was selected as a reader by the teacher. In most cases, all recipients had visual access to the text (see Table 1). In addition, the texts were from different sources. First, the texts could be drawn from textbooks or other learning materials, such as workbooks, hand-outs, texts written on a blackboard or whiteboard, and texts reflected on a big screen from either a computer or document camera. Second, participants read-aloud various types of fiction, such as poems, short stories, or extracts of novels that were read from original editions. Third, the texts read-aloud could also be student texts, including narratives or short factual texts written by individual students or in small groups. The length of the read-aloud activity varied from a few seconds by the teacher reading an instruction, or a student reading an answer, to almost fifteen minutes of the teacher's reading aloud a fictional story from an original edition.

From the material consisting of 28 lessons, we detected a total of 48 instances of reading aloud. Some occurrences consist of several sequences of reading aloud, and these subsequent or sequentially closely situated sequences are counted as one 
Table 1. Description of the variation in oral reading exercises.

\begin{tabular}{llrrr}
\hline Visual access to the text & \multicolumn{1}{c}{ Source } & $\begin{array}{c}\text { Student(s) } \\
\text { as reader(s) }\end{array}$ & $\begin{array}{c}\text { Teacher } \\
\text { as reader }\end{array}$ \\
\hline All participants have access & Textbooks and other learning materials & 19 & 16 & 35 \\
& instruction for a task & 1 & 13 & - \\
& answer to a task & 10 & 5 & 1 \\
non-fiction text & fictional text & 3 & 7 & 13 \\
& original editions of fiction & 1 & - & 23 \\
& student texts & 5 & 25 & 48 \\
\hline
\end{tabular}

occurrence (see, for instance, Example 1). The variation of oral reading in terms of access, genre, and source is presented in Table 1 . Since there are many text genres in textbooks and other learning materials, we have described them in more detail in the table.

According to the table, both students and teachers read frequently during L1 lessons. The most common sources for texts that are read-aloud are drawn from textbooks or other types of learning material, while fiction from original editions is read-aloud mostly by teachers to their students. Only two lessons consisted of the teacher presenting the aim of the read-aloud as performing art (see, for example, Goodman \& Goodman, 2013; Roe, 2014, pp. 164-165). In our data set, only students read student texts aloud, usually their own. However, teachers may also occasionally read student texts aloud in Finnish classrooms but our data set provided no instances of this.

In Table 1, the reading events are categorized into two groups in terms of the participants' visual access to the text. In most of the cases (35 out of 48), all the participants shared visual access to the text that was read-aloud. In these cases, all participants could follow the text from their own books or other sources. This has interactional implications that are analyzed in the following sections.

\section{Analyzing read-aloud practices}

We have divided the analytic section into two parts. In the first part we analyze examples where all participants have visual access to the text that is read-aloud, and in the second part we analyze examples where only the reader has visual access to the text. This has consequences particularly for embodied interactional practices, such as gaze. Let us now turn to analyze the four examples that we have selected as being representative of read-aloud practices.

\section{Shared visual access: reading-aloud learning materials}

Textbooks or other learning materials were read-aloud together in 20 lessons. Both the teacher and the students usually read-aloud from the same source during the same sequence. The teachers usually read-aloud task instructions, while the students 


\section{Tainio and A. Slotte}

read-aloud answers to them. In some instances, students were instructed to readaloud a factual text from a textbook or other learning material (see Example 2), on other occasions, a fictional text. Once a student was asked to read-aloud the instruction for a task. We will present examples of reading teacher instructions and student answers when reviewing homework (Example 1) as well as an example of a student reading aloud a non-fiction text (Example 2).

The topic of the exercises in Example (1) is Finnish grammar, and more specifically, the different forms of the genitive case in the plural. The teacher has read-aloud textbook instructions: "Inflect the words in the genitive case in plural into two different forms" (Salainen kerho, workbook, page 22; see Picture 1). In the instructions, the textbook provides a model of a word (maa, 'earth'), inflected into two different forms of the case. Just before this excerpt, the teacher has asked the students to pay attention to the next exercise and asked for the answer to the first exercise (see Picture 1, 2.a. hammas 'tooth'). After Frida (a student) answers, the teacher converses with her in a humorous tone, and at the beginning of the excerpt (line 1), she is still looking at Frida and smiling. On line 1, the word the teacher refers to is the second word, "lyhyt" (see Picture 1, task 2.b. lyhyt 'short').

Picture 1. The genitive case, plural.

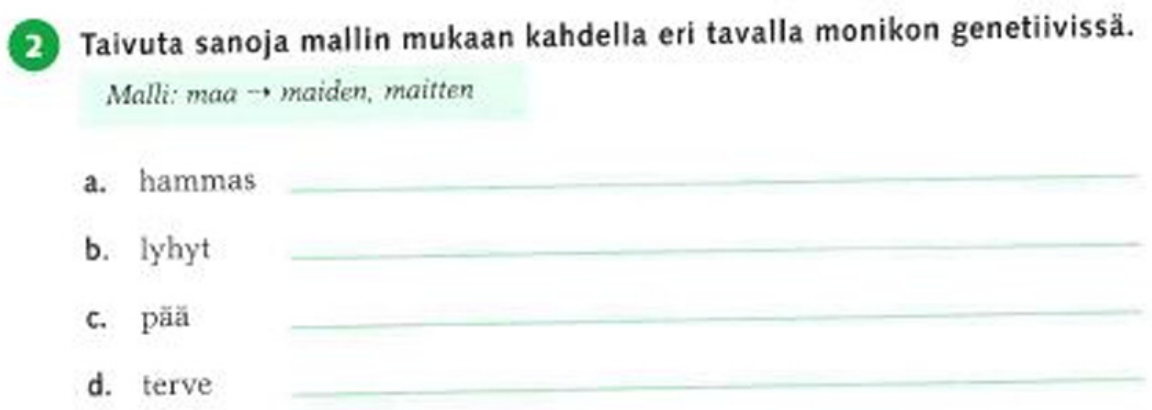

(1) $\left(\mathrm{Ls}_{6} \mathrm{~b}^{1}: 1.22 .10-\right)$

01 Teacher: [saat sanoo [seuraa[van. you may say the next one $[(($ looks at the text book $))$

[((loo[ks at Frida smiling) [((Frida glances at the teacher $))$

02 Frida: [öää (.) [lyhyiden lyhyitten.

$$
\begin{aligned}
& \text { shmm short short } \\
& (\text { Gen, PL) (Gen, PL) } \\
& {[((\text { smiles }))} \\
& {[((\text { looks at the book }))} \\
& {[((\text { teacher looks at the book }))}
\end{aligned}
$$

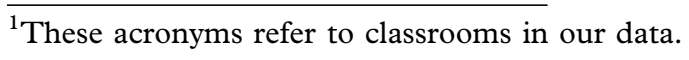


03 Teacher: [lyhyiden lyhyitt[en. (.) kol[me short short three

[((the teacher looks at the textbook $))$

[((many stud[ents raise their hands $))$

[((the teacher looks at the students $))$

04

[(.) Miina.

[((teacher looks at the students and at Miina))

05 Miina: [(on)kse[ päiden [päitten.

(is) it heads heads

(Gen, PL) (Gen, PL)

$[(($ looks at textbook $))$

[((looks straight forwards, smiling))

06 Teacher: [päiden päi[tten.

heads heads.

[((looks at Miina))

$[(($ looks at the textbook $))$

[((students begin to raise their hands))

07 Miina: päiden [päitten

heads heads

08 Teacher:

[nel[jä terve.

four healthy

$[(($ looks at students $))$

[((students begin to raise their hands))

09 Teacher: [(.) Au [ne.

[((teacher looks at Aune $))$

$[(($ looks at the textbook $))$

10 Aune: [onks (.) ter- (.) veiden (.) ja terveit[ten

is it heal- thy and healthy
(GEN, pl)
(GEN, pl)

[((Aune looks at the textbook))

[((looks at the teacher $))$

$[(($ teacher looks at the textbook $))$

This episode follows the routine of IRE sequences typical for classroom interaction (Mehan, 1979; Pitkänen-Huhta, 2003). While the teacher calls on Frida to be the person to answer next, the teacher first looks at the textbook and then turns her gaze to Frida (line 1). After that she and the teacher exchange a mutual gaze, and Frida then looks at the textbook and reads the answer aloud (line 2). Both the teacher and the students who answer use their gaze to express their intensive interaction with the text. The teacher predominately looks at her textbook, only glancing at the students when she calls on the next speaker. After selecting the student to answer (lines 1, 3-4 


\section{Tainio and A. Slotte}

and 8-9), she immediately turns her gaze back to the book. While the students answer, the teacher follows the answers with her gaze directed at her textbook (lines 2, 5 and 10). Students, on the other hand, look at their textbook while answering to indicate that they are reading aloud the answers (lines 2, 5 and 10). When they are finished reading, the students usually turn to look at the teacher (lines 5 and 10). Most of the students follow this routine even if they are not called on as the next speaker: they look at their books when their peer answers and then, at the end of the peer's answer, they turn their gaze towards the teacher. When the student completes his or her answer, and the teacher has accepted it by repeating it, and even before beginning to call on the next speaker, the students raise their hands.

The turn taking follows the design of the text and is routinized up to the point that the students know what the next question is and when it will be asked even before the teacher poses the question. This is evidenced in the smooth way the students look at their texts, turn to look at the teacher, and raise their hands to volunteer as the next speaker.

Although reading aloud excerpts from the textbook was the most typical readaloud activity, our data also contains many instances of reading aloud fiction or nonfiction texts other than instructions to exercises from textbooks or other learning materials. When reading aloud fiction in textbooks, the most common procedure is to read in turns. The teacher often selects the readers on a voluntary basis, but sometimes they read according to pre-planned order.

Our next example (2) represents the activity of reading a longer non-fiction text aloud. In these read-aloud events, reading the text functions as an introduction to the following exercise or task (see Roe 2014, p. 163). For example, in the next excerpt, the teacher requests that a student reads aloud a text on the "Litter movement" (Roska päivässä ${ }^{2}$ ). The aim is to use the text to analyze grammar - syntactic functions - but the teacher's way of introducing the text also reveals other pedagogic aims. Before the excerpt, the teacher begins to introduce a new exercise. She walks to her desk, picks up a paper, looks at it, and positions herself in front of the class (line 1):

(2) (Mm6b: 0.37.00)

(1.6) ((Teacher walks and looks at the paper she holds in her hand))

02 Teacher: [onks kukaan teistä koskaan kuullu sellasesta liikkee[stä kun] have any of you ever heard about such a movement as $[(($ looks at students $))$

[((glances at the paper $))]$

Roska päivässä liike.

Litter movement.

05 Teacher: [se on (.) †iännä systeemi joka on lähteny Suomest liikkeelle? - it is an exciting system that is originally invented in Finland - $[(($ looks at the students $))$

\footnotetext{
${ }^{2}$ See http://www.roskapaivassa.net/littermovement.htm).
} 
(( 1 minute 44 seconds omitted on the practical instructions for doing the grammar exercise))

06 Teacher: - - mut et $\uparrow$ sitä ennen hei luetaan tää juttu koska tää on but before that hey we read this story because this is aika mielenkiintonen. (.) luet sen sä: tota: [vaikkapaa: (.) quite interesting would you:: li:::ke [((looks at students at left, gazes then at Milli)) [Milli äänee tän koko, (.) koko jutun. (.) [tää on ihan totta. (.) tää Milli read-aloud the whole whole story this is really true this [((points to Milli with finger, looks at her $))$

$[(($ looks at all students $))$ ei oo mikään keksittyj [juttu. is not fict [ion. $[(($ looks at the text $))$

10 Milli: [ ["Roska päivässä liike." (.)

"Litter movement",

$[(($ starts reading $))$

Before Milli begins to read the text aloud, the teacher describes it in several ways to motivate students to be interested. First, she inquires whether any of the students has heard of the Litter movement (lines 2-3). The students look at the teacher without answering (line 4). The teacher emphasizes the importance of the movement by characterizing it as "an exciting system" that was invented in Finland (line 5). Then she gives practical instructions and distributes the text to all students. She then explains her instruction of reading the text aloud by characterizing the text as interesting (lines 6-7). After calling on Milli to be the reader, the teacher describes the text as a true story that is "not fiction" (lines 8-9). Following that description, Milli begins to read (line 10).

The introduction of the text reveals that the teacher's pedagogical aim in reading the text is not only to create a shared reference point for participants, but also to impart the content of the text. Even though she does not encourage her students to join this movement, she explains to them that this movement is highly acclaimed (exciting, interesting, true, and even originally Finnish). Many researchers have observed that while discussing the texts together, the teachers' position has an impact on the students' values and understandings of their texts and its meanings while discussing the texts they read together (Baker, 1991; Davidson et al., 2014; Gee, 2013). In the sequence described in Example (2), the reading aloud of the text was not necessary to complete the exercise, which involved identifying the predicates and subjects and marking these syntactic functions on paper. Rather, the aim that the teacher emphasizes is the sharing of the information and ideology that was mediated by the text. 


\section{Tainio and A. Slotte}

So, to summarize in relation to research question 2, the turn-taking routine described above in Example (1) is extremely common in the sequences that feature the topic of reviewing the answers to exercises printed in learning materials (see also Pitkänen-Huhta, 2003). All participants consider the text as a script to organize the turn-taking and the ongoing sequence. The process of teaching and learning is managed through the text, although it is carried out between participants. Furthermore, in the practice of reading aloud a non-fiction text (Example 2), creating a shared reference point and delivering important information could also be seen as one of the pedagogical aims. However, in the introduction of the text to be read-aloud, the teacher also presented other pedagogical aims, such as assuring that the ideology the text mediates is made public and emphasized.

\section{Private visual access: Reading aloud original editions and student texts}

In this section we analyze two examples that represent the interaction and pedagogical practices regarding the reading aloud of a text when only the reader has the visual access to the text. There are a total of 13 cases where either the teacher or student reads aloud fiction from an original edition or a student text. In Example (3), the teacher reads a fictional text aloud to students, and in the Example (4), a student reads her own text aloud to all participants.

Reading fiction aloud is recommended by literacy researchers as a practice that increases reading motivation and language awareness as well as fosters understanding of both the structure and the meaning of the text (Heath 1983; Roe, 2014). In Example (3), the teacher uses fiction, among other things, as a trigger to deepen the knowledge of geography (cf. Roe, 2014, p. 163). The text that the teacher reads aloud is Eric Campbell's novel, The Place of Lions, that tells of a boy who moves from London to Tanzania. Before this excerpt, the students and the teacher looked at a map and the teacher announced that "we are now in London," and then she begins to read. She sits relaxed in front of the classroom, bends her head towards the book, smilingly, and reads in a lively but clear and peaceful manner (see Johnston 2016). The excerpt begins at the point where the main character, Henry, is looking at a map:

(3) (Sms: 42.35)

01 Teacher: "[kartan fick liksom tiden att gå fortare, (2.0) han tog den varje dag (.) the map got the time to go faster he looked at it every day $[(($ looks at the book $))$ studerade den noga, (.) försökte lära sig alla [namn han såg” studied it carefully tried to learn all the names he saw [((looks at the students $))$

04 Teacher: och [nu får ni ta fram kartan and now you can pick up your own maps

[((looks at the students)) 
05

(.)

06 Max: (-)

07

(0.6) ((teacher turns her gaze at Max))

08 Teacher: [din egen karta (.) kartboken

your own map the atlas

[((looks at Max $))$

((24 sec omitted; students taking their atlases from desks))

09 Albert: vilken sida

which page

10 Teacher: [hör du sextiett

well sixty one

$[(($ looks at Albert $))$

11 Albert: $\quad \mathrm{mmm}<$ samma som Henri e $>$

mmm the same that Henry looked at

12 Teacher: samma [som Henri ejå $\mathrm{mh} \mathrm{hm} \mathrm{mh}$

the same that Henry looked at yes

$[(($ smiles $))$

13 Elin: $\quad$ va hette den dä staden

what was the name of that town

The teacher has carefully planned the read-aloud activity and relates it to other activities to be accomplished during the lesson. In this excerpt, she finishes reading when it is both topically and pedagogically relevant for her students to pick up their own atlases (line 2). The students show that they have been listening to the reading carefully. Albert points out that the teacher asks them to look at the same map as Henri, the main character in the book (line 11). In addition, Elin knows that they should be looking for a town (line 13). After answering Elin's question, the teacher tells her students that she is going to re-read the same paragraph. During the re-reading, the students study the map and attempt to locate the places that are mentioned in the fictional text. So, addressing to our research question 2, we can see that the teacher strongly involves the students in the fictive read-aloud episode. She does this by directly relating the activities in the classroom to the activities accomplished by the main character in the novel.

However, even if in this excerpt the teacher uses fiction as an integral part of a pedagogic aim connected to another subject, which here is geography, this was not the case in all of our examples. The teachers could introduce the activity of reading fiction aloud without giving it any particular reason, and the teachers did not always use the potential of the activity for other pedagogic purposes than for encouraging their students to enjoy literature and to engage in a peaceful moment 


\section{Tainio and A. Slotte}

in the classroom (see Clark \& Andreasen, 2014). This is possibly the case, for instance, in a lesson, not analyzed here in detail, where the teacher read an original edition aloud. At the beginning of the lesson, the teacher took the book in his hands and began his reading by saying: "Okay, listen, now we will continue with Kalle Knasterus and Miranda and see how the story goes." After reading nine minutes, he announced: "Well, we stop there for today, continue tomorrow, with the exciting continuation" (V26). In some classrooms, teachers asked their students either only a few rather superficial questions concerning the fictional texts or did not ask any questions at all. Our mutual impression in many cases was that the teacher used reading aloud more for filling up time than for developing their students' literacy skills. Nevertheless, as literacy researchers suggest, even the act of listening to the oral reading of fiction may influence literacy skills positively (Heath, 1983; Roe, 2014). In addition, oral reading of fiction offers students a peaceful space to relax and focus on another participant's performance (Clark \& Andreasen, 2014).

Our next Example (4) is from a lesson where students read their own texts aloud. One of the pedagogical practices recommended by writing pedagogues is to have students read-aloud their own texts. This helps students to find their "own voice," and it offers a platform for the reader and the listeners for sharing peer's emotions and views and for finding inspiration for their own writing (Murray, 2009, 20-21). In five lessons in our data, the students read-aloud their own texts or those of their peer's. However, according to our data, the teachers considered this practice of reading one's own text aloud to be slightly problematic. The teachers prepared students by offering the following encouragements: "I hope that as many of you as possible have the courage to read the text aloud because these are really nice stories" (Ls6b); "Prepare mentally then to read them aloud to others" (Pl6). However, in these classrooms students themselves express enthusiasm for reading their text aloud although teachers prepare them in this way, and as a result, students either volunteer to read or accept the teacher's invitation to read without hesitation.

In the lesson, where Example (4) is drawn, the teacher, who is rather new to this class, begins the lesson by asking the students whether they would like to read-aloud their own texts. When it is time for the read-aloud, he introduces the activity as being slightly problematic: "And now we need a lot of bravery, and the bravest starter is Arho." After Arho and another student have read their stories, the teacher and all students discussed student writing habits. After this discussion, the teacher asks whether some students have never read their story aloud to the class and whether they would like to read now. Several students volunteer, and the teacher selects one of them, Sanni. Sanni reads her story about a girl who moves to another town, in front of the classroom. Towards the end of the story, the teacher stands motionless in front of the class, and displays his concentration by focusing his gaze on a single spot in front of him (line 1). The next excerpt describes the situation after the reading. 
(4) (Sk6B)

01

02

03 Teacher:

04

05 Teacher: [ethän sä ook kos[kaan [muuttanu oikeesti. (.) you have never [((looks at Sanni $))$

06 Miitta:

07 Teacher:

08

09 Sanni:

((teacher stands and listens; Sanni finishes reading, smiles)) ((students start to applaud, teacher nods several times; Sanni stands up and starts walking to her desk))

miten $<$

how

(1.3) ((students applaud, most of them smile; Sanni smiles and walks)) really moved

[((Sanni looks at teacher, smiles $))$

[perfetto.

perfect (in Italian)

[((gesture by hands, looking at Sanni))

paikkakunnalta toi[selle. ethän.

from one place to another. have you.

[((looks at Sanni))

[((Sanni stops at her desk, looks at teacher $))$

(.)

[oon.

I have.

[((Sanni and teacher look at each other $))$

10 Teacher: [ [ = eli sulla on kokemusta tästä. (.) sitä saatoit

[käyttääh hyväks. (.) mä so you have experience on that (.) you could use it, (.) I $[(($ looks at Sanni $))$

[((Sanni sits down, smiles $))$

aattelin ensin että:, (0.9) että tota. (1.1) sä olit niinku. (0.5) hirvee first thought tha:t, that y'know you had like terribly hyvi eläytyny, (0.8) mielikuvituksev varassa ku sä oot, (1.0) siel löyty iha

well just imagined all this since you have, there was a oikee tarina. (.) [ $\uparrow$ kannattaa käyttää omaa kokemusta hyödyksi et jos sitä true story behind you should use your own experience if you have $[(($ looks at all students $))$

on. (.) siitä saa valtavastil lisätukea. (.) - -

it. $\quad y o u$ can get plenty of support from it 


\section{Tainio and A. Slotte}

The students have previously applauded all readers, and they also smile and applaud Sanni (lines 2-4). The teacher demonstrates his positive evaluation by nodding (line 2). As Sanni walks to her desk, with a smile, one of her peers looks at her, smiles and displays a playful gesture in Italian that means "perfect" (line 6). Immediately after Sanni's reading, the teacher begins to ask her about the content of the text (line 5). $\mathrm{He}$ asks whether the writer herself has experienced moving to a new place (lines 57). He then expresses appreciation that the story is based on "a true story" and that the writer had used her own experience as a resource when writing the story (lines 10-14). Indeed, instructions for creative writing often advise writers to use their own personal experiences (Murray 2009, 13). In our data, the teachers always commented on the content of the story or some details related to its milieu or characters in those classrooms where students volunteered to read their texts aloud. However, in those classrooms where the students were reluctant to read their texts aloud, the teacher's comments were minimal or focused on the possible language mistakes or problematic word choices.

Related to research question 2, in our data set, a teacher's behavior appears to be very important. The teachers model their reading or listening both verbally and with embodied activites. They show their orientation towards the read-aloud activity both by their gaze and body posture. With facial expressions they mediate enthusiasm, and with their body postures they show their concentration on the texts and readaloud activity. In this way the teachers model their students the appreciation of the read-aloud activity as well as the text's importance as a pedagogical artifact - and as a text itself.

\section{Discussion}

In this article, we have analyzed an interactional practice that is frequently used in L1 classrooms, the practice of reading aloud. We have focused on read-aloud practices in the sixth grade in Finnish comprehensive schools. By reading aloud we refer to practices where participants read-aloud all kinds of texts, including textbooks, fiction, student texts, and written excerpts from other sources. The pedagogic aims of L1 education focus on texts, as the main goal of mother tongue lessons, is to help students develop their literacy skills.

We chose to analyze read-alouds in the sixth grade, since there is a lack of research on reading aloud activities in classrooms in this age group. In addition, at least in Finland, students of this age are already fairly fluent readers technically but in a position where they should develop their literacy skill in order to be prepared for lower secondary school. After the sixth grade they enter in the lower secondary school where more complex and critical literacy skills are required.

Although the practice of reading aloud is very familiar both to teachers and students, the characteristics of interaction before, during, and after read-alouds in the sixth grade have seldom been explored empirically in detail. In this article we have empirically analyzed four representative examples of read-aloud practices, 
selected from the data set of video-recorded mother tongue lessons, using the method of conversation analysis.

We discovered that in our data of $28 \mathrm{~L} 1$ lessons, in all but one of the lessons, either the teacher or students read-aloud texts. This was surprising for us, since reading aloud is not mentioned in the Finnish national curriculum, and it is not mentioned as a frequent pedagogic activity by teachers of mother tongue lessons (see e.g. Harjunen $\&$ Rautopuro, 2015). What was also news was that the range of texts that were readaloud was extremely wide.

Our analysis demonstrates that the practice of oral reading includes a range of activities that all have a common pedagogic goal: to create a shared reference point. However, we also identified many additional goals. We divided the practice of oral reading into two main categories in terms of visual access to the text which was shown particularly in reference to embodied, nonverbal interaction. The importance of embodied interaction, such as gaze, gestures, postures, facial expressions and moving around in the classroom, is as highly influential in classroom interaction as in other face-to-face situations (Sidnell \& Stivers, 2013, pp. 281-349). This is why we see the participant displays of access or non-access to the text as an important feature that affects the organization of the interaction as well as the pedagogical opportunities that reading aloud offers.

For instance, from the perspective of addressing and controlling the gaze, according to our data, when participants share visual access to the textbook or other learning material that a teacher or student is reading aloud, the participants share a somewhat covert norm: they usually follow the teacher's or their peer's reading from the text available in their own book (cf. Clark \& Andreasen, 2014). This norm becomes even more evident during a lesson in our data where the teacher explicitly instructs restless students who are gazing elsewhere to turn their gaze to their own textbook and follow the reading from there. In contrast to that, if a teacher or a student reads fiction from an original edition, or student reads aloud his/her own text, the reader is the only one that has visual access to the text. In these occurrences, the teacher does not control the recipients' gaze, even though silent student participation is typically still required, as an evidence of active listening. Active listening is displayed by the recipients' verbal and embodied responses, which are connected both to the embodied activities of the teacher as well as to the content of the text.

From a pedagogical perspective, reading aloud creates a shared verbal reference point by showing students not only the learning target and space for demonstrating learning in and through interaction, but also as it directs the coordination, timing and order of their turn taking. The design of the text can heavily influence the turntaking order. Even during the most routine turn-taking base on the IRE sequences that are intertwined with the text (Example 1), by looking at the text and by turning one's gaze to the primary recipients in turns, the reader, the recipients and the text participate in an intimate pedagogic interaction. It is thus important to notice that the interaction with the text in read-aloud events is carefully demonstrated not only by verbal practices, but also by embodied interactional practices, particularly gaze 


\section{Tainio and A. Slotte}

and body posture. In all the examples, the teachers acted as models for the students in terms of how they interacted with texts. This was displayed in their interaction by various non-verbal practices, such as by ways of holding the text and gazing at it and the recipients, and through a variation in gestures and body postures. With the direction of her/his gaze and body posture the teacher constructs and models the interaction between the reader and the text, and emphasizes the importance of the shared reference point for students. These embodied activities were addressed to mediate the act of reading aloud as a moment of respect and joy.

The embodied activities underline the importance of the activity of reading aloud. But not only is the act of reading emphasized but the teachers also use multiple verbal means for emphasizing the content of the texts for students. It can be emphasized in the introduction to the text which is then realized by reading the text aloud (Example 2). It is also possible to use texts to inform students and deepen knowledge on various subject fields (Example 3). The text and the production of the text may also be emphasized and made relevant by discussing the content of the text in connection to the writing process (Example 4). During the act of reading, the teacher and the students usually participate actively by showing concentration on listening, by commenting on the details or content of the stories and by laughing at the humorous points (Examples 3 and 4). These all create a space for sharing information, values, cultural meanings, structures and models of language and textual genres, as well as emotions, interpretations and attitudes. According to several studies, sharing a text with others increases the language learner's motivation to read and write (for example, see Guthrie \& Wigfield, 2000; Roe, 2014). Furthermore, an active involvement with the text in discussions or otherwise is highly appreciated particularly by those students that themselves like reading and find it interesting (Clark \& Andreasen, 2014).

In addition, since positive classroom atmosphere in itself promotes positive attitudes towards learning (e.g., Clark \& Andreasen, 2014), reading aloud can be used as an effective tool for creating positive atmosphere in the classroom. Reading aloud a fictional or nonfictional text provides all participants with a relaxed moment of being together with shared interactional and intellectual focus. In creating these moments, teacher behavior is important, both during student and teacher readalouds. However, particularly for student read-alouds, teacher behavior is of the utmost significance. According to our data, in the classrooms where students volunteer enthusiastically to read, the teachers create verbally and non-verbally a peaceful space for readers and present reading aloud as an activity that requires courage (see Example 4). During the reading, the teachers both listen actively, showing it in embodied ways, and guarantee an interactional space for reading. After the students have finished reading, the teachers comment on the content of the story rather than, for example, mistakes or occasional, unconnected linguistic details in it. Particularly the teacher, but also the students, usually give positive feedback on the text or the reading. In this moment, they demonstrate their involvement in the text and the reading activity. Through the encouragement of these interactional strategies, it is possible to create a pedagogically productive space where students 
can develop their writings skills, share a peer's efforts, support and encourage a writer, and obtain ideas for their own writing processes.

In this article, we have conducted a detailed analysis of representative examples of those practices that occurred smoothly in terms of interaction. In addition we suggested these practices as being beneficial to teaching and developing literacy skills. The detailed analyses of read-aloud practices may offer us research-based information for teachers and student teachers on how these practices can be used to foster pedagogic interaction (Drake, Land \& Tyminsky, 2015). There is an urgent need for this type of knowledge, particularly in teacher education where the skills of using various kinds of texts, such as textbooks and other printed or digital learning materials, should be promoted as an integral and important part of education. However, there is little information available on how and why this practice is actually carried out during the rich interactional environment of classrooms. Further empirical research is therefore needed.

\section{References}

Albright, L. K. \& Ariail, M. (2005). Tapping the potential of teacher read-alouds in middle schools. Fournal of Adolescent $\mathcal{E}$ Adult Literacy, 48, 582-591.

Ariail, M. \& Albright, L. K. (2006). A survey of teachers' read-aloud practices in middle schools. Literacy Research and Instruction, 45, 69-89.

Bagga Gupta, S., Evaldsson, A.-C., Liberg, C. \& Säljö, R. (Eds.). (2013). Literacy-praktiker i och utanför skolan. Malmö: Gleerups.

Baker, C. D. (1991). Literacy practices and social relations in classroom reading events. In C. D. Baker \& A. Luke (Eds.), Towards a Critical Sociology of Reading Pedagogy: Papers of the XII World Congress on Reading (pp. 161-189). Amsterdam/Philadelphia: John Benjamins.

Baker, C. D. (1997). Ethnomethodological studies of talk in educational settings. In B. Davies \& D. Corson (Eds.), Encyclopedia of language and education. Vol. 3: Oral discourse and education (pp. 43-52). Netherlands: Kluwer Academic Publishers.

Clark, S. K. \& Andreasen, L. (2014). Examining sixth grade students' reading attitudes and perceptions of teacher read aloud: Are all students on the same page? Literacy Research and Instruction, 53(2), 162-182. doi: http://dx.doi.org/10.1080/19388071.2013.870262

Davidson, C. (2012). Ethnomethodology and literacy research: A methodological "road less travelled". English Teaching: Practice and Critique, 11, 26-42.

Davidson, C., Danby, S. J., Given, L. M. \& Thorpe, K. J. (2014). Talk about a YouTube video in preschool: the mutual production of shared understanding for learning with digital technology. Australasian fournal of Early Childhood, 39, 76-83.

Damber, U. (2015). Read-alouds in preschool - A matter of discipline? Fournal of Early Childhood Literacy, 15, $256-280$.

Drake, C., Land, T. J. \& Tyminski, A. M. (2015). Using Educative Curriculum Materials to Support the Development of Prospective Teachers' Knowledge. Educational Researcher, 43(3), 154-162. doi: http://dx.doi. org/10.3102/0013189X14528039

Femø Nielsen, M. (2012). Using artifacts in brainstorming sessions to secure participation and decouple sequentiality. Discourse Studies, 14, 87-109.

Ford, C. (1999). Collaborative construction of task activity: Coordinating multiple resources in a high school physics lab. Research on Language and Social Interaction, 32, 369-408.

Gee, J. P. (2013). Reading as situated language. A sociocognitive perspective. In D. E. Alvermann, R. B. Ruddell \& N. J. Unrau (Eds.), Theoretical models and processes of reading (6th edition) (pp. 136-151). Newark, DE: International Reading Association.

Goodman, Y. M. \& Goodman, K. S. (2013). To err is human: Learning about language processes by analyzing miscues. In D. E. Alvermann, R. B. Ruddell \& N. J. Unrau (Eds.), Theoretical models and processes of reading (6th edition), (pp. 525-543). Newark, DE: International Reading Association. 


\section{Tainio and A. Slotte}

Goodwin, C. (2007). Participation, stance and affect in the organisation of activities. Discourse and Society, 18(1), 53-73.

Guthrie, J. T. \& Wigfield, A. (2000). Engagement and motivation in reading. In M. L. Kamil, P. B. Mosenthal, P. D. Pearson \& R. Barr (Eds.), Handbook of reading research, vol. 3, (pp. 403-422). New Jersey: Lawrence Erlbaum Associates.

Harjunen, E. \& Rautopuro, J. (2015). Kielenkäytön ajattelua ja ajattelun kielentämistä. Äidinkielen ja kirjallisuuden oppimistulokset perusopetuksen päättövaiheessa: keskiössä kielentuntemus ja kirjoittaminen. [Learning outcomes in mother tongue and literature in the end of basic education. Focus on grammar and writing.] Julkaisut 2015: 8. Kansallinen koulutuksen arviointikeskus. [See https://karvi.fi/publication/kielenkayton-ajattelua-ja-ajattelun-kielentamista/ Accessed 11.1.2017.]

Heap, J. L. (1991). A situated perspective on what counts as reading. In C. D. Baker \& A. Luke (Eds.), Towards a Critical Sociology of Reading Pedagogy: Papers of the XII World Congress on Reading (pp. 103-140). Amsterdam/Philadelphia: John Benjamins.

Heath, S. B. (1983). Ways with words: language, life, and work in communities and classrooms. Cambridge: Cambridge University Press.

Houtkoop-Steenstra, H. (2000). Interaction and the standardized survey interview: the living questionnaire. Cambridge: Cambridge University Press.

Jakonen, T. (2015). Handling knowledge: Using classroom materials to construct and interpret information requests. Fournal of Pragmatics, 89, 100-112. doi: http://dx.doi.org/10.1016/j.pragma.2015.10.001

Johnston, V. (2016). Successful read-alouds in today's classroom. Kappa Delta Pi Record, 52, 39-42.

Karvonen, U., Tainio, L., Routarinne, S. \& Slotte, A. (2015). Tekstit selitysten resursseina oppitunnilla [Texts as resources for explanations in classroom interaction]. Puhe ja kieli, 4/2015, 189-207. doi: http://ojs.tsv.fi/ index.php/pk/article/view/55388/18194

Mehan, H. (1979). Learning lessons. Social organization in the classroom. Cambridge: Harvard UniversityPress.

Melander, H. \& Sahlström, F. (2010). Lärande i interaktion. Stockholm: Liber.

Mikkola, P. \& Lehtinen, E. (2014). Initiating activity shifts through use of appraisal forms as material objects during performance appraisal interviews. In M. Nevile, P. Haddington, T. Heinemann \& M. Rauniomaa (Eds.), Interacting with Objects. Language, materiality and social activity (pp. 57-79). Amsterdam: John Benjamins.

Mondada, L. (2011). The interactional production of multiple spatialities within a participatory democracy meeting. Social Semiotics, 12, 283-308.

Murray, D. M. (2009). The essential Don Murray: Lessons from America's greatest writing teacher. In T. Newkirk \& L. C. Miller (Eds.), Portsmouth: Boynton/Cook Publishers Heinemann.

Musk, N. \& Cekaite, A. (2015). Mobilising distributed memory resources to solve language problems in English project work. In Å. Mäkitalo, P. Linell \& R. Säljö (Eds.), Memory practices and learning: interactional, institutional and sociocultural perspectives. Information Age Publishing, incorporated, Charlotte, NC.

Nevile, M., Haddington, P., Heinemann, T. \& Rauniomaa, M. (Eds.). (2014). Interacting with Objects. Language, materiality and social activity. Amsterdam: John Benjamins B. V.

PIRLS 2012 = Mullis, I.V.S., Martin, M., Minnich, C. A., Drucker, K.T. \& Ragan, M.A. (2012). PIRLS 2011 Encyclopedia. Education Policy and Curriculum in Reading. Volume 1: A-K. TIMSS \& PIRLS International Study Center, Lynch School of Education, Boston College.

Pitkänen-Huhta, A. (2003). Texts and interaction. Literacy practices in the EFL Classroom. Jyväskylä Studies in Languages 55. Jyväskylä: Jyväskylän yliopisto.

Reschly, A. L., Busch, T. W., Betts, J., Deno, S. L. \& Long, J. D. (2009). Curriculum-Based Measurement Oral Reading as an indicator of reading achievement: a meta-analysis of a correlational evidence. Fournal of School Psychology, 47, 427-469.

Roe, A. (2014 [2011]). Läsdidaktik. Efter den första läsinlärningen. versättning Birgitta Önnerfält. Malmö: Gleerups.

Rusk, F., Pörn, M., Sahlström, F. \& Slotte-Lüttge, A. (2015). Perspectives on using video recordings in conversation analytical studies on learning in interaction. International fournal of Research $\mathcal{E}$ Method in Education, 38, 39-55. doi: http://dx.doi.org/10.1080/1743727X.2014.903918

Sidnell, J. \& Stivers, T. (Eds.) (2013). The handbook of conversation analysis. Chichester, UK: Wiley-Blackwell.

Tainio, L. (2012). The role of textbooks in Finnish mother tongue and literature classrooms. In H. Lehti-Eklund, A. Slotte-Lüttge, B. Silén \& R. Heilä-Ylikallio (Eds.), Skriftpraktiker hos barn och unga, (pp. 11-33). Rapport 35/ 2012. Vasa: Pedagogiska fakulteten vid Åbo Akademi. 


\section{Interactional Organization and Pedagogic}

Tainio, L. \& Grünthal, S. (2012). Language and literature education: Principles and reflections on Mother tongue and literature. In H. Niemi, A. Toom \& A. Kallioniemi (Eds.), The Miracle of Education (pp. 149-160). Rotterdam/Boston/Taipei: Sense Publishers.

Tainio, L. \& Laine, A. (2015a). Emotion work and affective stance in the mathematics classroom: the case of IRE sequences in Finnish classroom interaction. Educational Studies in Mathematics, 89(1), s. 67-87. doi: http://dx.doi.org/10.1007/s10649-015-9591-5

Tainio, L. \& Siponmaa, E. (2015b). Lukukoira ei hauku - Koira, lapsilukija ja aikuiset lukemistapahtuman rakentajina [Therapy dog doesn't criticise. Therapy dog, child and adults as participants in a reading event.]. Kasvatus, 3, 364-378.

Tanner, M. (2014). Lärarens väg genom klassrummet. Lärande och skriftspråkande $i$ bänkinteraktioner på mellanstadier. Karlstad University Studies 2014: 27. Karlstad: Fakulteten för humaniora och samhällsvetenskap, Institutionen för pedagogiska studier.

TextMix (2014). Textmix. http://blogs.helsinki.fi/textmixblogi/ 
L. Tainio and A. Slotte

Appendix. Transcription conventions.

\begin{tabular}{ll}
\hline[] & Point of overlap onset and termination \\
$=$ & No interval between adjacent utterances \\
$(0.6)$ & Interval between adjacent \\
$()$. & Short untimed pause \\
word & Speaker emphasis \\
e:r & Lengthening of the sound \\
- & Abrupt cut-off \\
$? /, /$. & Rising/low rising/falling intonation \\
WORD & Loud sounds relative to surrounding talk \\
$\downarrow \uparrow$ & Marked shifts into higher or lower pitch \\
$(())$ & Transcriber's comment \\
\hline
\end{tabular}

